\title{
Anemia and its mechanism in goldfish Carassius auratus infected with Trypanosoma danilewskyi
}

\author{
A. K. M. Nazrul Islam, Patrick T. K. Woo* \\ Department of Zoology, University of Guelph, Guelph, Ontario, Canada N1G 2W1
}

\begin{abstract}
Trypanosoma danilewskyi Laveran \& Mesnil, 1904 caused anemia in goldfish Carassius auratus. The severity of the anemia was associated with high parasitemia. At least 2 factors are responsible for the anemia; (1) hemolysin: a secretory/excretory product of living trypanosomes which lyses red blood cells ( $\mathrm{rbc}$ ) in the absence of antibody (in vitro study) and (2) hemodilution (in vivo study). No significant hemolysis was detected when rbc were added to sonicated trypanosomes. The hemolysis and hemodilution were correlated with numbers of parasites. Secretion/excretion of hemolysin by living trypanosomes was associated with declining $\mathrm{pH}$ in the incubation medium but the $\mathrm{pH}$ itself was not involved in hemolysis.
\end{abstract}

\section{INTRODUCTION}

Most piscine trypanosomes are not pathogenic, however Trypanosoma danilewskyi Laveran \& Mesnil, 1904 causes mortality in experimentally infected goldfish Carassius auratus (Lom 1979, Woo 1981b). The parasite has been found in common carp Cyprinus carpio, crucian carp Carassius auratus gibelio, tench Tinca tinca and eel Anguilla sp. in Europe (Lom 1979). It is not host specific (Woo \& Black 1984) and its development and multiplication in fish have been described (Robertson 1911, Woo 1981a).

Trypanosoma danilewskyi causes anemia in infected goldfish (Robertson 1911, Dykova \& Lom 1979). Anemia is also associated with other piscine Trypanosoma (Becker 1977, Khan 1985, Lom 1979) and Cryptobia (Woo 1979, 1987) species. In a recent study, Thomas \& Woo (1988) showed that the anemia in cryptobiosis is in part caused by hemolysin from the parasite and formation of an immune complex on red blood cells ( $\mathrm{rbc}$ ).

In the present study, in vivo and in vitro approaches were used to determine factors contributing to anemia in goldfish infected with Trypanosoma danilewskyi.

\footnotetext{
- Author for correspondence
}

\section{MATERIALS AND METHODS}

The strain of Trypanosoma danilewskyi used in the present study was that used in earlier studies (Woo $1981 \mathrm{a}, \mathrm{b})$.

Goldfish were infected by intraperitoneal injection. Number of parasites was estimated using a hemocytometer (Archer 1965) and goldfish (average $7.35 \mathrm{~g}$; 4.70 to $10.56 \mathrm{~g}$ ) bought from a local supplier were maintained as before (Islam \& Woo 1990). Blood from heavily infected fish was collected into a heparinized syringe, dispensed into microhematocrit tubes, sealed at one end and centrifuged for $4 \mathrm{~min}$ at $13000 \times \mathrm{g}$. The tubes were cut at the junction of the buffy coat and packed red cells (Woo 1969). Parasite suspensions, free of red cells, were washed 3 times in cold Ringer's solution and the number of parasites determined. The parasites in Ringer's solution (1.0 to $1.5 \mathrm{ml})$ were sonicated at $12 \mathrm{kHz}$ for $15 \mathrm{~min}$ in an ice bath. A drop of sonicated material was examined under the microscope to ensure that there were no intact parasites. The antigen was used fresh or dispensed in $1 \mathrm{ml}$ aliquots to tubes and stored in liquid nitrogen.

Fish rbc were washed thrice in Ringer's solution before they were used. Hemoglobin was assayed in the incubation medium after rbc were incubated with parasites in a tube. The tube was centrifuged for $10 \mathrm{~min}$ in 
the refrigerated centrifuge at $4000 \times g_{i} 0.02 \mathrm{ml}$ (Eppendorf micropipette) of supernatant was dispensed into $5 \mathrm{ml}$ of Drabkin's solution in a borosilicate glass tube. Light absorbance was read in a spectrophotometer and plotted on a standard curve to determine hemoglobin concentration. The standard curve was prepared by plotting absorbance reading against the concentration of a standard set of cyanmethemoglobin.

\section{Experimental design}

Anemia in infected goldiish. Each goldfish was infected with ca 19500 parasites. They were divided into 2 groups and were maintained at $20 \pm 1{ }^{\circ} \mathrm{C}$ and 10 $\pm 1{ }^{\circ} \mathrm{C}$. Five goldfish from each group were killed weekly; the number of $\mathrm{rbc}$, the parasitemia and the packed cell volume (pcv) were determined for $7 \mathrm{wk}$.

The experiment was repeated with another group of 30 fish which were inoculated with 30000 parasites fish $^{-1}$. Three fish were bled at $0,7,12,17,22,27,32$, and $38 \mathrm{~d}$ post-infection and the parasitemia and number of rbc was determined in each fish. The freeflowing blood was collected and the total blood volume measured using an Eppendorf micropipette. Fish were weighed and blood volume was expressed as $\mu \mathrm{l} \mathrm{g}^{-1}$ body weight of fish. The relationships between blood volumes and parasite numbers (log-transformed) were determined by fitting the data to a quadratic regression model

In vitro study on hemolysis. The study was done aseptically. Two approaches were used after incubation of rbc with live or sonicated parasites on slides/ tubes: (1) determine lysis by counting intact $\mathrm{rbc}_{\text {, }}$ or (2) determine hemoglobin released and $\mathrm{pH}$ changes in the medium.

1. Reduction in number of rbc on exposure to live or sonicated trypanosomes: A known number of rbc were mixed with a known number of parasites. A drop of the mixture was dispensed onto a glass slide, covered with a vaseline-ringed coverslip and placed under a microscope. Before and after incubation for a specified period the number of $\mathrm{rbc}$ on the slide were determined either in a predetermined high power microscopic field or in a marked area on a slide. Alternatively, a known number of rbc and parasites were incubated in a tube. After incubation the remaining intact rbc were counted to determine the number of lysed rbc.

Incubation of $r b c$ with live parasites: In this experiment $0.25 \%$ rbc was incubated with 4 million $\mathrm{ml}^{-1}$ live parasites at $20 \pm 1{ }^{\circ} \mathrm{C}$ for $7 \mathrm{~h}$. In the control $0.25 \%$ rbc was incubated in Ringer's solution. The number of lysed rbc in a microscopic field on each slide was counted hourly. The experiment was repeated with 8 million parasites $\mathrm{ml}^{-1}$.
Incubation of rbc with live and sonicated parasites: A suspension of 100 million washed parasites was suspended in $2 \mathrm{ml}$ of Ringer's solution. One ml (50 million parasites) was placed into a tube and diluted serially by 2 -fold dilutions $\left(25,12.5\right.$, and 6.25 million $\left.\mathrm{ml}^{-1}\right)$. To each tube $0.5 \mathrm{ml}$ of $2 \%$ rbc was added so that the final concentrations of parasites were $12.5,6.25$ and 3.125 million $\mathrm{ml}^{-1}$. Three drops from each tube were dispensed on 3 different slides and covered with vaselineringed coverslips $(22 \times 22 \mathrm{~mm})$. Each slide was set under a microscope for $10 \mathrm{~h}$ at room temperature $(20 \pm$ $1{ }^{\circ} \mathrm{C}$ ). The controls (no parasites) had a $1 \%$ rbc suspension. Intact rbc in a predetermined microscope field were counted every $2 \mathrm{~h}$.

The other 50 million parasites (in $1 \mathrm{ml}$ Ringer's solution) were sonicated and a similar set of 4 slides was prepared using sonicated parasites after appropriate antigen dilutions.

The number of lysed rbc was converted to percentage lysis. The data were transformed into arc-sine percentages before statistical analysis. Though the experiments were run for $10 \mathrm{~h}$, results from the first $6 \mathrm{~h}$ were used in the analysis because there was $100 \%$ hemolysis at $6 \mathrm{~h}$ in the microscope field with 12.5 million parasites $\mathrm{ml}^{-1}$. A strip-split-plot design was used to determine the difference between live and sonicated parasites and a split-plot design to determine the effects of number of parasites, incubation periods, and their interaction effects on lysis by live or sonicated parasites. Duncan's multiple range test (DMRT), which compared the mean of lysed rbc, was eventually used to compare the number of parasites and incubation periods.

Quadratic regression models are used to establish the relationship between incubation periods and lysis of rbc. In this case original percentage data were used and lysis of all incubation periods was included.

2. Hemoglobin released from rbc on incubation with live parasites and $\mathrm{pH}$ changes in medium: Incubation of $r b c$ with live parasites: A 8.42 million $\mathrm{ml}^{-1} \mathrm{rbc}$ suspension was incubated with $11.05 \mathrm{million}^{-1} \mathrm{ml}^{-1}$ live parasites at 10 and $20^{\circ} \mathrm{C}$. Another 2 sets of incubate (one for each temperature) were prepared with only 11.05 million $\mathrm{ml}^{-1}$ parasites in Ringer's solution. The controls contained only rbc. Hemoglobin released and $\mathrm{pH}$ changes were recorded after $6 \mathrm{~h}$.

The experiment was repeated with $2 \% \mathrm{rbc}$ in 200 , 100 , and 30 million $\mathrm{ml}^{-1}$ parasites at $20^{\circ} \mathrm{C}$ for $9 \mathrm{~h}$. Released hemoglobin and $\mathrm{pH}$ changes were determined every $3 \mathrm{~h}$.

The experiment was repeated again with 2 " rbc and $30,20,10$, and 0.00 (control) million parasites $\mathrm{ml}^{-1}$ at $20^{\circ} \mathrm{C}$ for $10 \mathrm{~h}$. Hemoglobin and $\mathrm{pH}$ changes were recorded every $2 \mathrm{~h}$

Data were analysed using a split-plot design. DMRT 
was used to compare the mean of released hemoglobin and the changes in $\mathrm{pH}$. Regression analysis was carried out to determine the relationship between incubation period, the amount of hemoglobin, and the $\mathrm{pH}$.

Incubation of rbc with live or sonicated parasites: Six $\mathrm{ml}$ of live parasites in Ringer's solution were divided into 2 equal parts. Three $\mathrm{ml}$ (100 million parasites $\mathrm{ml}^{-1}$ ) were dispensed into a $13 \times 100 \mathrm{~mm}$ sterile borosilicate glass tube and diluted serially by 2 -fold dilutions such that the final concentrations in 4 tubes were 50, 25 , 12.5, and 6.25 million $\mathrm{ml}^{-1}$ Washed rbc $(100 \mu \mathrm{l})$ were added to each tube to obtain a final $4 \%$. The content of each tube was dispensed (in $0.5 \mathrm{ml}$ aliquots) into 6 sterile microcentrifuge tubes. The control was $100 \mu \mathrm{l}$ of $4 \% \mathrm{rbc}$ in $3 \mathrm{ml}$ Ringer's solution. Every $2 \mathrm{~h}$ one tube from each parasite concentration and one control were used to determine the released hemoglobin and $\mathrm{pH}$ changes. There were 3 replicates for each concentration of parasite. The incubation time was $10 \mathrm{~h}$.

Another series was prepared using the remaining half of parasite suspension (same protocol) but sonicated parasite was used instead. This saline used was taken from a different stock (the initial $\mathrm{pH}$ was slightly different from the stock used in the experiment with live parasites)

A strip-split-plot design was used to determine the differences between live and sonicated parasite and a split-plot design was used to determine the effect of number of parasites, incubation periods, and their interaction on $\mathrm{pH}$. DMRT, which compared the mean $\mathrm{pH}$ changes, was eventually used to compare the number of parasites and incubation periods. A correlation analysis was done to determine the relationship between $\mathrm{pH}$ and hemoglobin. Finally, data were fitted to a regression model to establish the relationship between incubation periods and $\mathrm{pH}$.

\section{RESULTS}

\section{Anemia in infected goldfish}

Infected fish held at $20^{\circ} \mathrm{C}$ were anemic (low numbers of rbc and pcv) during the course of the infections. The anemia was most severe in fish which had massive parasitemias. There was a negative correlation between numbers of rbc (and pcv) and numbers of parasites (Table 1). The numbers of rbc (and pcv) decreased significantly at high parasitemias. Although numbers of $\mathrm{rbc}$ and $\mathrm{pcv}$ declined at $10^{\circ} \mathrm{C}$ there was no correlation with parasitemias (Table 1 ).

There was an increase in blood volume in infected goldfish when the parasitemia was high. However, the increase was not significant when compared with control fish. As a group there was a direct relationship
Table 1. Carassius auratus. Correlation between blood parameters and parasite numbers in goldfish infected with $T_{r y}$ panosoma danilewskyi

\begin{tabular}{|lccc|}
\hline $\begin{array}{l}\text { Temp. } \\
\text { group }\end{array}$ & $\begin{array}{c}\text { Blood } \\
\text { parameter }\end{array}$ & df & $\begin{array}{c}\text { Calculated } \\
\text { rvalue }\end{array}$ \\
\hline $20^{\circ} \mathrm{C}$ & Rbc & 31 & $-0.460^{\circ}$ \\
& PCV & 31 & $-0.416^{\circ}$ \\
$10^{\circ} \mathrm{C}$ & RbC & 33 & $-0.170^{\text {ns }}$ \\
& PCV & 33 & $-0.021^{\text {ns }}$ \\
$\cdots$ Significant at 1 \% level & & \\
Significant at 5\% level & & \\
ns Not significant & & \\
\end{tabular}

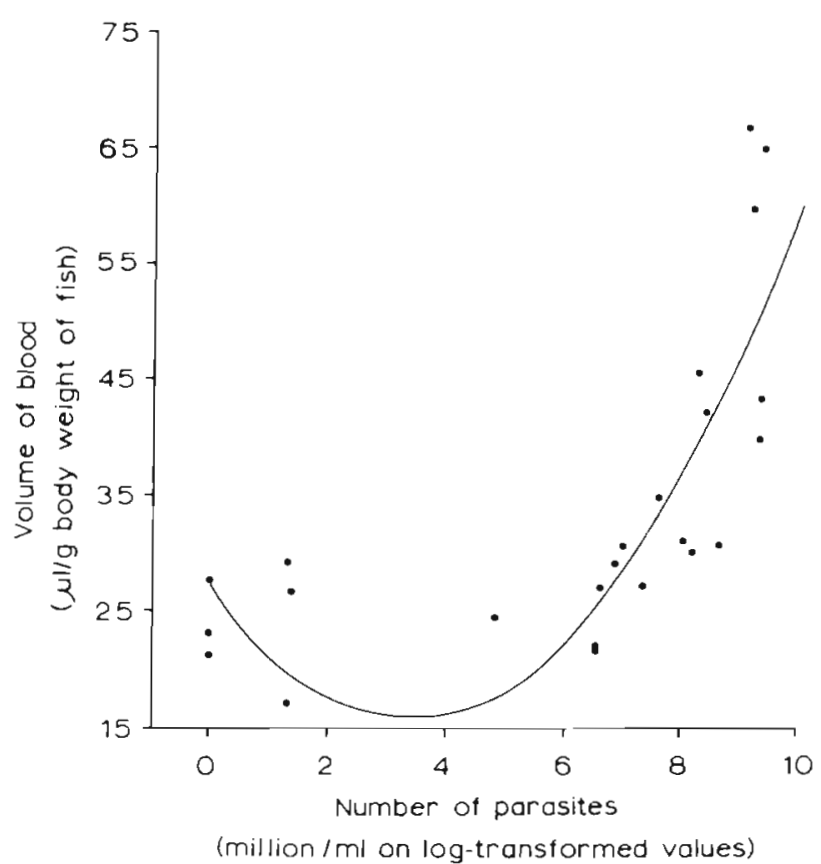

Fig. 1 Carassius auratus. Relationship between blood volume and number of parasites (data are log-transformed) in Trypanosoma danilewskyi infected goldfish maintained at $20^{\circ} \mathrm{C}$. $\mathrm{Y}=27.077-6.81 \mathrm{X}+1.008 \mathrm{X}^{2} ; \mathrm{R}^{2}=0.70 ; \mathrm{p}<0.0001$ where $\mathrm{Y}=$ volume of blood, $\mathrm{X}=$ number of parasites

between the blood volume and numbers of parasites. After a lag period the blood volume increased rapidly with increasing numbers of parasites and this is expressed in a quadratic regression model (Fig. 1).

\section{In vitro study on hemolysis}

Reduction in number of rbc on exposure to live or sonicated trypanosomes

Incubation of rbc with live parasites. There was ca $56 \%$ lysis of rbc after $7 \mathrm{~h}$ of incubation with 4 million 
Table 2. Number of goldfish rbc (in $0.25 \%$ suspension) lysed after incubation with live Trypanosoma danilewskyi in Ringer's solution at $20^{\circ} \mathrm{C}$. Values are no. of rbc lysed in a microscopic field (eyepiece $x$ objective) with percentage lysis in parenthesis

\begin{tabular}{|c|c|c|c|c|c|c|c|c|c|}
\hline \multirow{2}{*}{$\begin{array}{l}\text { No. of } \\
\text { parasites } \\
\left(\times 10^{6} \mathrm{ml}^{-1}\right)\end{array}$} & \multirow{2}{*}{$\begin{array}{c}\text { Initial no of rbc } \\
\text { in microscopic } \\
\text { field }\end{array}$} & \multicolumn{8}{|c|}{ Incubation period $(\mathrm{h})$} \\
\hline & & 0 & 1 & 2 & 3 & 4 & 5 & 6 & 7 \\
\hline 4.00 & 207 & $\begin{array}{l}0 \\
(0.00)\end{array}$ & $\begin{array}{l}3 \\
(1.45)\end{array}$ & $\begin{array}{l}5 \\
\{2.42\}\end{array}$ & $\begin{array}{l}10 \\
(4.83)\end{array}$ & $\begin{array}{l}16 \\
(7.73)\end{array}$ & $\begin{array}{l}56 \\
(27.05)\end{array}$ & $\begin{array}{l}78 \\
(37.68)\end{array}$ & $\begin{array}{l}115 \\
(55.56)\end{array}$ \\
\hline 0.00 & 121 & $\begin{array}{l}0 \\
(0.00)\end{array}$ & $\begin{array}{l}3 \\
(2.48)\end{array}$ & $\begin{array}{l}3 \\
(2.48)\end{array}$ & $\begin{array}{l}4 \\
(3.31)\end{array}$ & $\begin{array}{l}4 \\
(3.31)\end{array}$ & $\begin{array}{l}7 \\
(5.79)\end{array}$ & $\begin{array}{l}10 \\
(8.27)\end{array}$ & $\begin{array}{l}17 \\
(14.05)\end{array}$ \\
\hline 8.00 & 224 & $\begin{array}{l}0 \\
(0.00)\end{array}$ & $\begin{array}{l}2 \\
(0.89)\end{array}$ & $\begin{array}{l}32 \\
(14.29)\end{array}$ & $\begin{array}{l}64 \\
(28.57)\end{array}$ & $\begin{array}{l}159 \\
(70.98)\end{array}$ & $\begin{array}{l}216 \\
(96.43)\end{array}$ & $\begin{array}{l}224 \\
(100.00)\end{array}$ & $\begin{array}{l}\text { not } \\
\text { done }\end{array}$ \\
\hline 0.00 & 122 & $\begin{array}{l}0 \\
(0.00)\end{array}$ & $\begin{array}{l}6 \\
(4.92)\end{array}$ & $\begin{array}{l}10 \\
(8.20)\end{array}$ & $\begin{array}{c}13 \\
(10.66)\end{array}$ & $\begin{array}{l}14 \\
(11.48)\end{array}$ & $\begin{array}{l}15 \\
(12.30)\end{array}$ & $\begin{array}{l}16 \\
(13.12)\end{array}$ & $\begin{array}{l}\text { not } \\
\text { done }\end{array}$ \\
\hline
\end{tabular}

live parasites $\mathrm{ml}^{-1}$ (Table 2). This was about $400 \%$ more than in the controls (without parasites).

The experiment was repeated and $100 \%$ lysis was observed after $6 \mathrm{~h}$ when 8 million parasites $\mathrm{ml}^{-1}$ were used. In the control group there was $13 \%$ hemolysis (Table 2). No significant differences were detected when rbc was incubated with or without sonicated parasite (at $20^{\circ} \mathrm{C}$ or at $10^{\circ} \mathrm{C}$ ).

Incubation of rbc with live or sonicated parasites. A significantly higher number of rbc were lysed when they were incubated with live parasites than with sonicated parasites $(p<0.002)$. Hemolysis increased with the number of live parasites $(p<0.0001)$ and incubation period ( $\mathrm{p}<0.0001$ ) (Table 3 ). It increased rapidly after a lag period and is described by a quadratic regression model (Fig. 2). Highest lysis (100\% after 6 h) was observed with 12.5 million $\mathrm{ml}^{-1}$ parasites and this was followed by $6.25,3.125$, and 0.0 (control) million $\mathrm{ml}^{-1}$ parasites respectively (Table 3 ).

There were some hemolysis when rbc were incubated with sonicated parasites. However, this did not increase with parasite number as observed with live parasites (Table 3). Hemolysis increased with incubation: this included the controls without parasite antigen.

Hemoglobin released from rbc on incubation with live parasites and $\mathrm{pH}$ changes

Incubation of rbc with live parasites. Hemoglobin was detected after $6 \mathrm{~h}$ incubation at $20^{\circ} \mathrm{C}$ with live parasites but not in the controls (without parasites). No hemoglobin was detected at $10^{\circ} \mathrm{C}$. The $\mathrm{pH}$ declined in experimental (parasites and $\mathrm{rbc}$ ) tubes and in tubes with parasites only. The decrease was greater at $20^{\circ} \mathrm{C}$ than at $10^{\circ} \mathrm{C}$.

Results were similar when the experiments was repeated (Table 4). The amount of hemoglobin released was higher in tubes with larger numbers of parasites (0.45 $\mathrm{mg} \mathrm{dl}^{-1}$ with 200 million $\mathrm{ml}^{-1}$ parasites). No hemoglobin was detected in the controls. The pH declined in all experimental groups (greatest decrease with 200 million $\mathrm{ml}^{-1}$ parasites). No decrease in $\mathrm{pH}$ was observed in the controls.

Table 3. Duncan s multiple range test (alpha $=5 \%$ with $16 \mathrm{df}$ ) of percentage rbclysed (mean of arc-sine-transformed percentage data) with different numbers of parasites and incubation periods. Total incubation period was 10 h (five 2 h incubation periods). As lysis of rbc reached $100 \%$ with 12.5 million $\mathrm{ml}^{-1}$ parasites after $6 \mathrm{~h}$ of incubation, only data up to $6 \mathrm{~h}$ were included. Means with the same letter are not significantly different.

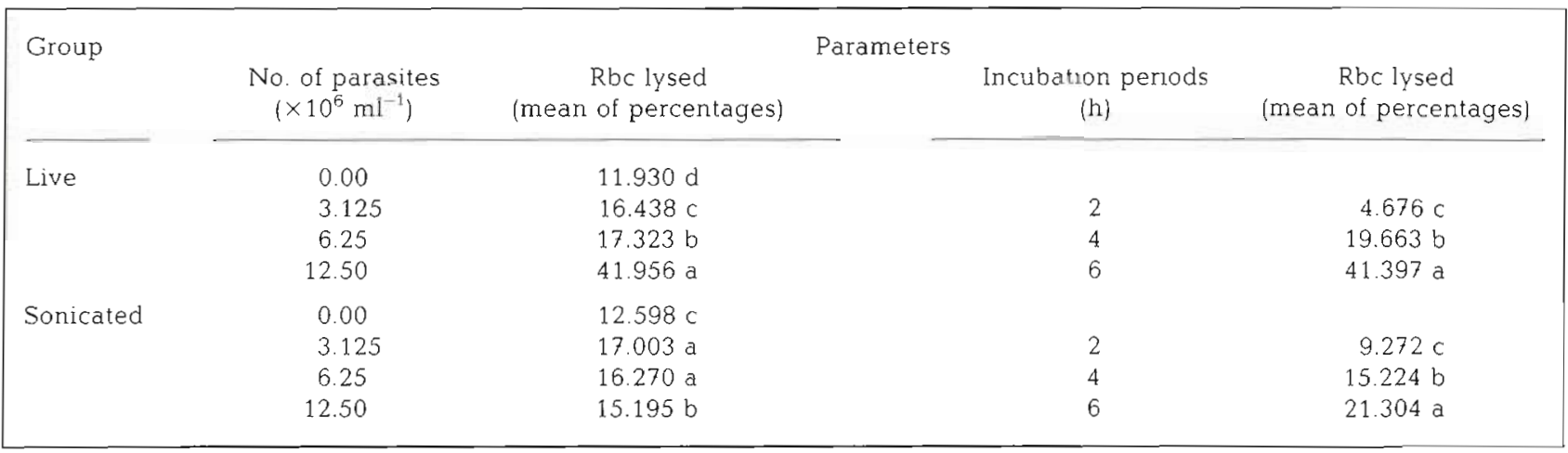




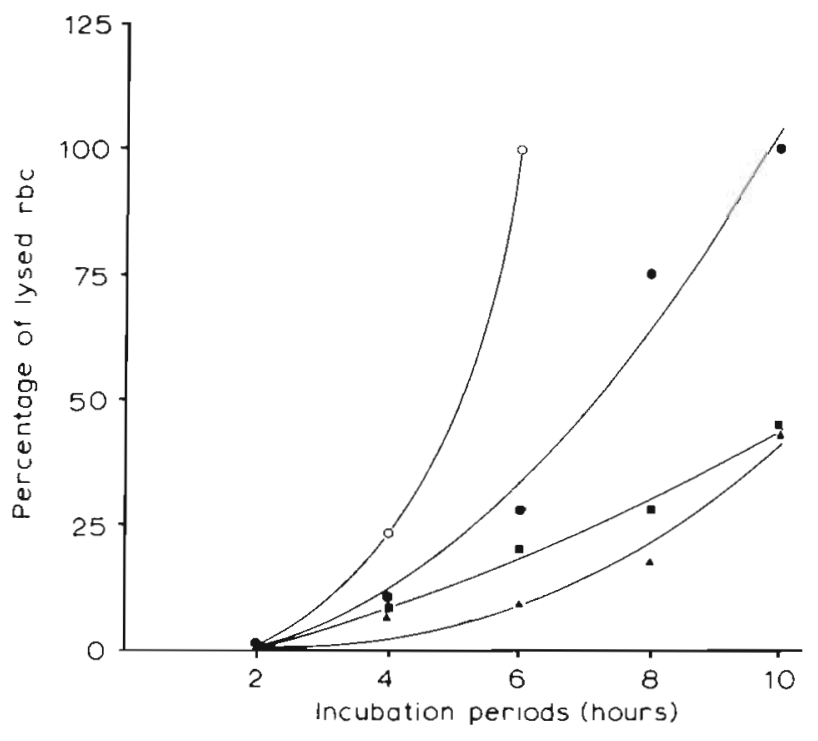

Fig. 2. Carassius auratus. In vitro lysis of goldfish rbc (\%) when incubated with different numbers of live Trypanosoma danilewskyi. (^) $0.0 \times 10^{6}$ parasites $\mathrm{ml}^{-1}: \mathrm{Y}=8.937-4.903 \mathrm{X}+$ $0.813 \mathrm{X}^{2} ; \mathrm{R}^{2}=0.97 ; \mathrm{p}<0.0001$. (-) $3.125 \times 10^{6}$ parasites $\mathrm{ml}^{-1}: \mathrm{Y}$ $=3.874+1.987 X+0.282 X^{2} ; R^{2}=0.99 i p<0.0001$ (•) $6.25 \times 10^{6}$ parasites $\mathrm{ml}^{-1}: \mathrm{Y}=5.737+1.100 \mathrm{X}^{2} ; \mathrm{R}^{2}=0.98$; $\mathrm{p}<0.0001$. (o) $12.5 \times 10^{6}$ parasites $\mathrm{ml}^{-1} \cdot \mathrm{Y}=33.680-29.634 \mathrm{X}$ $+6.781 \mathrm{X}^{2} ; \mathrm{R}^{2}=0.99 ; \mathrm{p}<0.0001$ where $\mathrm{Y}=$ percentage of lysed rbc, $\mathrm{X}=$ incubation period (h)

The experiment was repeated again with $0,10,20$, and 30 million $\mathrm{ml}^{-1}$ live parasite and, again, results were similar (Fig. 3). Large amounts of hemoglobin were released when high numbers of parasites were used $(p<0.0001)$ and with prolonged incubation $(\mathrm{p}<0.0001)$. Most parasites were dead in tubes after $8 \mathrm{~h}\left(30\right.$ million $\left.\mathrm{ml}^{-1}\right)$ or $10 \mathrm{~h}\left(20\right.$ million $\left.\mathrm{ml}^{-1}\right)$.

The $\mathrm{pH}$ declined with incubation $(\mathrm{p}<0.0001)$ and numbers of parasites ( $p<0.0001$ ) (Fig. 4). The decline continued up to 4,6 , and $8 \mathrm{~h}$ with 30 million, 20 million, and 10 million $\mathrm{ml}^{-1}$ respectively. The changes in $\mathrm{pH}$ are expressed by a quadratic regression model (Fig. 4). The maximum decline in the $\mathrm{pH}$ (from 7.073 to 5.063 ) was after $4 \mathrm{~h}$ with 30 million $\mathrm{ml}^{-1}$.

Incubation of rbc with live or sonicated parasites. No hemoglobin was detected when rbc were incubated

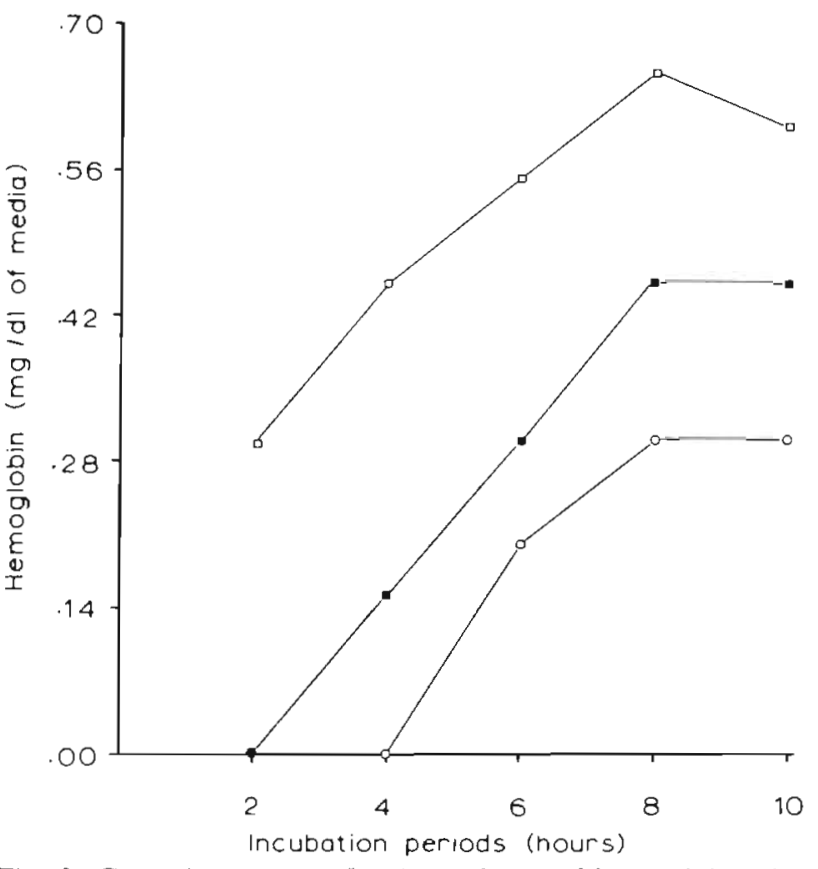

Fig. 3. Carassius auratus. In vitro release of hemoglobin during incubation of goldfish rbc with different numbers of live Trypanosoma danilewskyi; no hemoglobin was detected in controls where rbc were incubated with no parasites. (0) $10 \times$ $10^{6}$ parasites $\mathrm{ml}^{-1} ;$ (घ) $20 \times 10^{6}$ parasites $\mathrm{ml}^{-1} ;$ (口) $30 \times 10^{6}$ parasites $\mathrm{ml}^{-1}$

with sonicated parasites. Hemoglobin was detected only when rbc were incubated with live parasites; the amount increased with incubation $(p<0.0001)$ and parasite numbers $(p<0.0002$ ) (Table 5 ). The most hemoglobin released $\left(0.60 \mathrm{mg} \mathrm{dl}^{-1}\right)$ was at $10 \mathrm{~h}$ incubation with 50 million $\mathrm{ml}^{-1}$ live parasites; no hemoglobin was detected with 0.0 to 6.25 million $\mathrm{ml}^{-1}$ parasites. Hemoglobin was first detected after 4 h of incubation in the media with 50 million $\mathrm{ml}^{-1}$ parasites and 8 and $10 \mathrm{~h}$ of incubation in media with 25 and 12.5 million $\mathrm{ml}^{-1}$ parasites respectively (Fig. 5 ).

Changes in $\mathrm{pH}$ were observed in the incubation media. These were significantly lower in preparations with live parasites than with sonicated parasites $(p<0.0001)$. Drop in $\mathrm{pH}$ was related to number of parasites and incubation period $(p<0.0001$ in both)

Table 4. Released hemoglobin and changes in $\mathrm{pH}$ of Ringer's solution in which goldfish rbc ( $2 \%$ suspension) were incubated (at $20^{\circ} \mathrm{C}$ ) with live Trypanosoma danilewskyi

\begin{tabular}{|c|c|c|c|c|c|c|c|c|}
\hline \multirow{2}{*}{$\begin{array}{l}\text { No. of } \\
\text { parasites } \\
\left(\times 10^{6} \mathrm{ml}^{-1}\right)\end{array}$} & \multicolumn{8}{|c|}{ Hemoglobin ( $\mathrm{mg} \mathrm{dl}^{-1}$ ) } \\
\hline & 0 & 3 & 6 & 9 & 0 & 3 & 6 & 9 \\
\hline 200.00 & 0.00 & 0.00 & 0.45 & 0.60 & 7.94 & 6.13 & 5.03 & 4.86 \\
\hline 100.00 & 0.00 & 0.00 & 0.15 & 0.30 & 7.94 & 7.02 & 6.57 & 5.69 \\
\hline 30.00 & 0.00 & 0.00 & 0.00 & 0.15 & 7.94 & 7.69 & 7.52 & 7.45 \\
\hline 0.00 & 0.00 & 0.00 & 0.00 & 0.00 & 7.94 & 7.90 & 7.83 & 8.01 \\
\hline
\end{tabular}




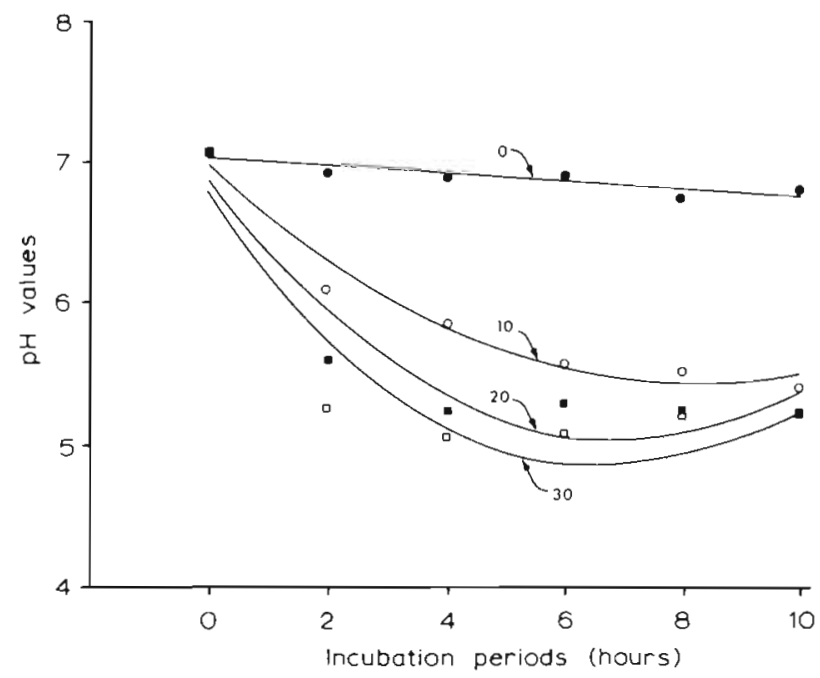

Fig. 4. Carassius auratus. pH changes during incubation of goldfish $r b c$ with different numbers of Trypanosoma danilewskyi. (•) $0 \times 10^{6}$ parasites $\mathrm{ml}^{-1}: \mathrm{Y}=7.023-0.030 \mathrm{X}$; $\mathrm{R}^{2}=0.81 ; \mathrm{p}<0.0001$. (10 $10 \times 10^{6}$ parasites $\mathrm{ml}^{-1}: \mathrm{Y}=6.962$ $0.379 X+0.023 X^{2} ; R^{2}=0.96 ; \mathrm{p}<0.0001$. (-) $20 \times 10^{6}$ parasites $\mathrm{ml}^{-1}: \mathrm{Y}=6.848-0.528 \mathrm{X}+0.038 \mathrm{X}^{2} ; \mathrm{R}^{2}=0.89 ; \mathrm{p}<0.0001$. (口) $30 \times 10^{6}$ parasites $\mathrm{ml}^{-1}: \mathrm{Y}=7.778-0.599 \mathrm{X}+0.050 \mathrm{X}^{2}$ $\mathrm{R}^{2}=0.84 ; \mathrm{p}<0.0001$ where $\mathrm{Y}=\mathrm{pH}, \mathrm{X}=$ incubation period (h)

Table 5. Duncan's multiple range test (alpha $=5 \%$ with $24 \mathrm{df}$ ) for released hemoglobin (mean) with different numbers of live parasite and incubation periods. No detectable hemoglobin was released with control ( 0 parasites) and $6.25 \times 10^{6}$ parasites $\mathrm{ml}^{-1}$ Means with the same letter are not significantly different

\begin{tabular}{|lcccc}
\hline $\begin{array}{l}\text { No. of } \\
\text { parasites } \\
\left(\times 10^{6} \mathrm{ml}^{-1}\right)\end{array}$ & $\begin{array}{c}\text { Mean } \\
\text { hemoglobin }\end{array}$ & & $\begin{array}{c}\text { Incubation } \\
\text { period }(\mathrm{h})\end{array}$ & $\begin{array}{c}\text { Mean } \\
\text { hemoglobin }\end{array}$ \\
\hline 12.5 & $0.03 \mathrm{c}$ & 2 & $0.00 \mathrm{c}$ \\
25.0 & $0.10 \mathrm{~b}$ & 4 & $0.03 \mathrm{C}$ \\
50.0 & $0.24 \mathrm{a}$ & 6 & $0.05 \mathrm{C}$ \\
& & 8 & $0.20 \mathrm{~b}$ \\
& & 10 & $0.33 \mathrm{a}$ \\
\hline
\end{tabular}

and the changes are expressed in a quadratic regression model. The lowest $\mathrm{pH}$ (5.41) was observed in the media with 50 million parasites $\mathrm{ml}^{-1}$ after $10 \mathrm{~h}$ (Fig. 6). In contrast the $\mathrm{pH}$ in control tubes did not change significantly. Most of the parasites were dead in the tubes with 50 million $\mathrm{ml}^{-1}$ after $8 \mathrm{~h}$ and were sluggish in tubes with $25,12.5$, and 6.25 million parasites $\mathrm{ml}^{-1}$.

There was a slight decrease in $\mathrm{pH}$ with increasing number of sonicated parasites. Unlike with live parasites these changes were not dependent on length of incubation.

Finally, no hemoglobin was detected when rbc were incubated for $10 \mathrm{~h}$ in Ringer's solutions at $\mathrm{pH} 7.75,7.25$, $6.75,6.25$, and 5.75 .

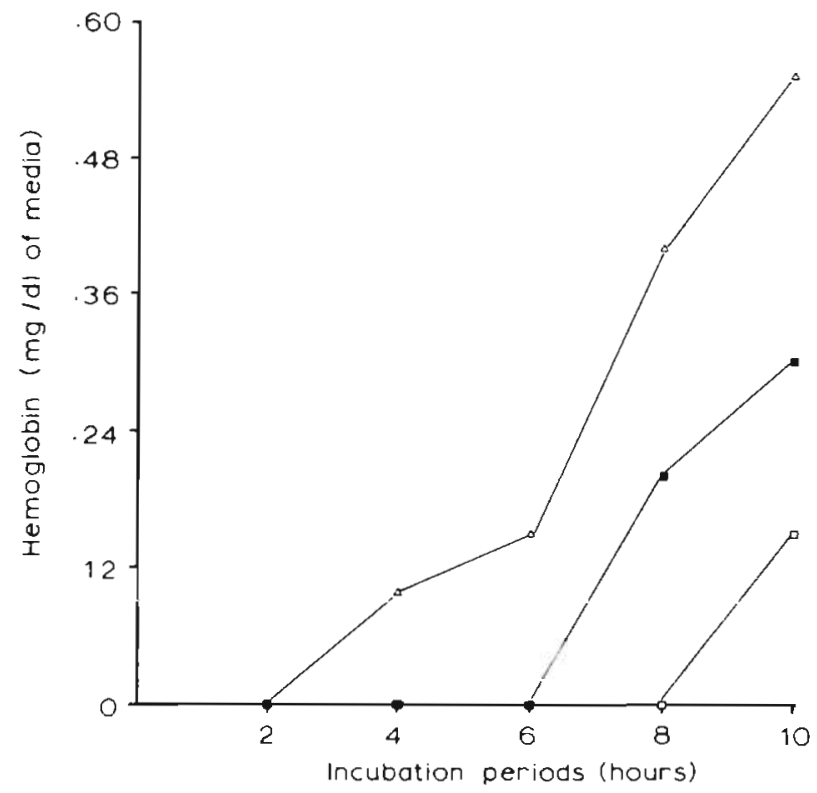

Fig. 5. Carassius auratus. In vitro release of hemoglobin by rbc with different numbers of Trypanosoma danilewskyi; no hemoglobin was detected when 0 parasites $\mathrm{ml}^{-1}$ (control) and $6.25 \times 10^{6}$ parasites $\mathrm{ml}^{-1}$ were incubated with rbc. (c) $12.5 \times$ $10^{6}$ parasites $\mathrm{ml}^{-1}:(\bullet) 25.0 \times 10^{6}$ parasites $\mathrm{ml}^{-1} ;(\Delta) 50.0 \times 10^{6}$ parasites $\mathrm{ml}^{-1}$

\section{DISCUSSION}

Trypanosoma danilewskyi cause a severe anemia in goldfish at, or following, peak parasitemias. The negative correlation between numbers of rbc (and pcv) and parasitemias indicates that lysis of $\mathrm{rbc}$ is dependent on parasitemia. Anemia is one of the clinical signs in piscine trypanosomiasis (Lom 1979, Khan 1985) and cryptobiosis (Woo 1979, 1987). Severity of the anemia in cryptobiosis is related to parasite numbers in the blood (Woo 1979, 1987. Thomas \& Woo 1988).

The present study demonstrates that there are at least 2 factors which contribute to anemia in goldfish infected with Trypanosoma danilewskyi. The first is a 'hemolytic factor' (hemolysin) present in the secretory/ excretory product of the trypanosome which causes direct hemolysis of $\mathrm{rbc}$. In vitro incubation of rbc from naive goldfish and live trypanosomes indicated that the hemolysis increased with numbers of trypanosomes and incubation period. The second factor is 'hemodilution' (increased blood volume) which was at. or following, the peak parasitemia. Increased blood volume was correlated with the increased numbers of parasites.

Thomas \& Woo (1988) showed that there are 2 basic components in Cryptobia salmositica that are responsible for the anemia in cryptobiosis. A lytic component, which is dosage dependent, causes hemolysis indepen- 


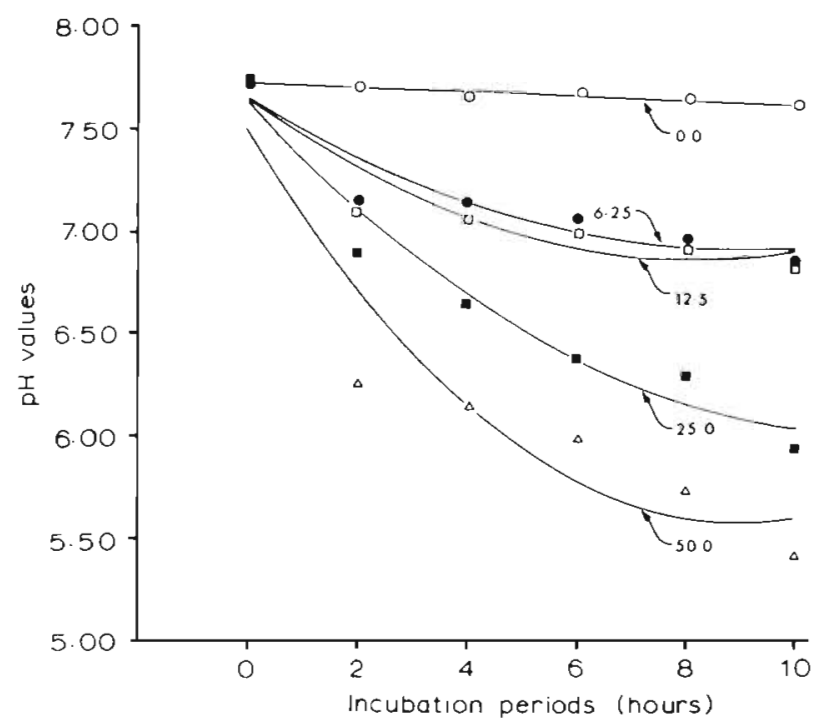

Fig. 6. Carassius auratus. $\mathrm{pH}$ change when goldfish rbc were incubated with different numbers of live Trypanosoma danilewskiy. (0) $0.0 \times 10^{6}$ parasites $\mathrm{ml}^{-1}: \mathrm{Y}=7.720-0.010 \mathrm{X}$; $\mathrm{R}^{2}=0.74 ; \mathrm{p}<0.0001 .\left(\bullet 6.25 \times 10^{6}\right.$ parasites $\mathrm{ml}^{-1}: \mathrm{Y}=7.631-$ $0.166 \mathrm{X}+0.009 \mathrm{X}^{2} ; \mathrm{R}^{2}=0.86 ; \mathrm{p}<0.0001$. (a) $12.50 \times 10^{6}$ parasites $\mathrm{ml}^{-1}: \mathrm{Y}=7.638-0.198 \mathrm{X}+0.012 \mathrm{X}^{2} ; \mathrm{R}^{2}=0.89 ; \mathrm{p}$ $<0.0001$. (匹) $25.00 \times 10^{6}$ parasites $\mathrm{ml}^{-1}: \mathrm{Y}=7.625-0.291 \mathrm{X}+$ $0.013 \mathrm{X}^{2} ; \mathrm{R}^{2}=0.96 ; \mathrm{p}<0.0001(\Delta) 50.00 \times 10^{6}$ parasites $\mathrm{ml}^{-1}$ : $\mathrm{Y}=7.479-0.431 \mathrm{X}+0.024 \mathrm{X}^{2} ; \mathrm{R}^{2}=0.88 ; \mathrm{p}>0.0001$ where $\mathrm{Y}=\mathrm{pH}, \mathrm{X}=$ incubation period $(\mathrm{h})$

dent of antibody or complement, and a second immune-complex-forming component activates complement resulting in lysis. Hemodilution occurs in cгурtobiosis as a result of generalized edema and may contribute to anemia (Woo 1979). In many respects the mechanism of anemia in trypanosomiasis is similar to that in cryptobiosis.

Dykova \& Lom (1979) found severe histopathological changes in hemopoetic organs (i.e. spleen and kidney) in fish infected with Trypanosoma danilewskyi. Consequently, they suggested a relationship between the lesions and the blood profile, namely that anemia in infected goldfish is due to the malfunctioning of the spleen and insufficient compensatory hemopoetic capacity of the kidney interstitium.

The decline in $\mathrm{pH}$ during incubation of $\mathrm{rbc}$ with live parasites was probably due to excretory/secretory products of parasites. Similar declines in $\mathrm{pH}$ ( $\mathrm{pH} 8.0$ to 5.5) were observd in Trypanosoma congolense (Tizard \& Holmes 1976). In the present study, as the parasites died because of changes in $\mathrm{pH}$ and depletion of nutrients, release of secretory/excretory product decreased. Hence there were no further declines in $\mathrm{pH}$ during the last hours of incubation ( 8 to $10 \mathrm{~h}$ ).

Responsible Subject Editor: W. Körting, Hannover, Germany
The slight initial decline in $\mathrm{pH}$ in preparations with sonicated parasites may be caused by the release of metabolic products by the trypanosomes (prior to sonication) and biological products of the cells (e.g. enzymes, cell fragments) which are released during sonication. There was little decrease in $\mathrm{pH}$ during the latter incubation periods.

Acknowledgement. This study was supported by a grant from the Natural Sciences and Engineering Research Council of Canada to P.T.K.W

\section{LITERATURE CITED}

Archer, R. K. (1965). Haematological techniques for use on animals. Blackwell Scientific Publications, Oxford

Becker, C. D. (1977). Flagellate parasites of fish,. In: Kreier, J. P. (ed.) Parasitic Protozoa, Vol. 1. Academic Press, New York, p. $358-416$

Dykova, I., Lom, J. (1979). Histopathological changes in Trypanosoma danilewskyi Laveran \& Mesnil, 1904 and Trypanoplasma borelli Laveran \& Mesnil, 1902, infections of goldfish, Carassius auratus (L.). J. Fish. Dis. 2: 381-390

Islam, A. K. M. N., Woo, P. T. K. (1991). Anorexia in goldfish Carassius auratus infected with Trypanosoma danilewskyi. Dis. aquat. Org. 11:45-48

Khan, R. A. (1985). Pathogenesis of Trypanosoma murmanensis in marine fish of the northwestern Atlantic following experimental transmission. Can. J. Zool. 63: 2141-2144

Lom, J. (1979). Biology of trypanosomes and trypanoplasms of fish. In: Lumsden, W. H. R., Evans, D. A. (eds.) Biology of the Kinetoplastida, Vol.2. Academic Press, London, p. 269-337

Robertson, M. (1911). II. Transmission of flagellates living in the blood of certian freshwater fishes. Trans. R. Phil. Soc. Series B 202: 29-50

Thomas, P. T., Woo, P. T K. (1988). Cryptobia salmositica: an in vitro and in vivo study on the mechanism of anaemia in infected rainbow trout, Salmo gairdneri Richardson. J. Fish Dis. $11 \quad 425-431$

Tizard, I. R., Holmes, W L. (1976). The generation of toxic activity from Trypanosoma congolense. Experientia 32: $1533-1534$

Woo, P. T K. (1969). The haematocrit centrifuge for the detection of trypanosomes in blood. Can. J. Zool. 47: 921-923

Woo, P. T K (1979). Trypanosoma salmositica: experimental infections in rainbow trout, Salmo gairdneri. Expl Parasitol. $47: 36-48$

Woo, P. T. K. (1981a). Trypanosoma danilewskyi:a new multiplication process for Trypanosoma (Protozoa: Kinetoplastida). J. Parasitol. 67: 522-526

Woo, P. T. K. (1981b). Acquired immunity against Trypanosoma danilewskyi in goldfish, Carassius auratus. Parasitology 83: 343-346

Woo, P. T K. (1987). Cryptobia and cryptobiosis in fishes. Adv. Parasitol. 26: 199-239

Woo, P. T. K., Black, G. A. (1984). Trypanosoma danilewskyi: host specificity and host's effect on morphometrics. J. Parasitol. 70: 788-793

Manuscript first received: April 18, 1990

Revised version accepted: April 10, 1991

(Several months delay due to loss of manuscript in the mail) 